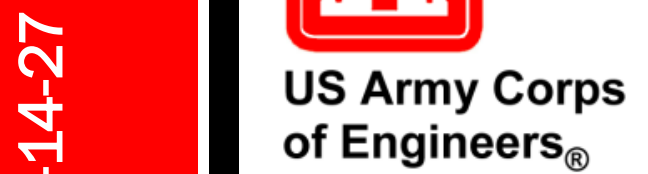

Engineer Research and

Development Center

\section{ERDC}

INNOVATIVE SOLUTIONS

for a safer, better world

\title{
Avian and Herpetological Survey Results for Fairchild Air Force Base and Ancillary Properties
}

Jinelle H. Sperry

October 2014

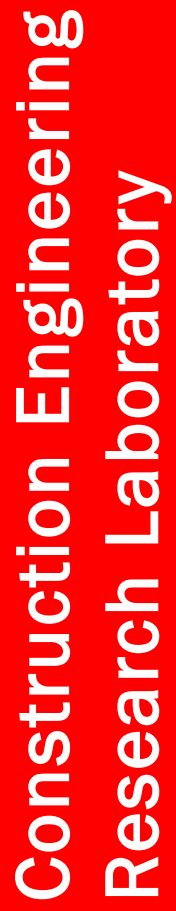

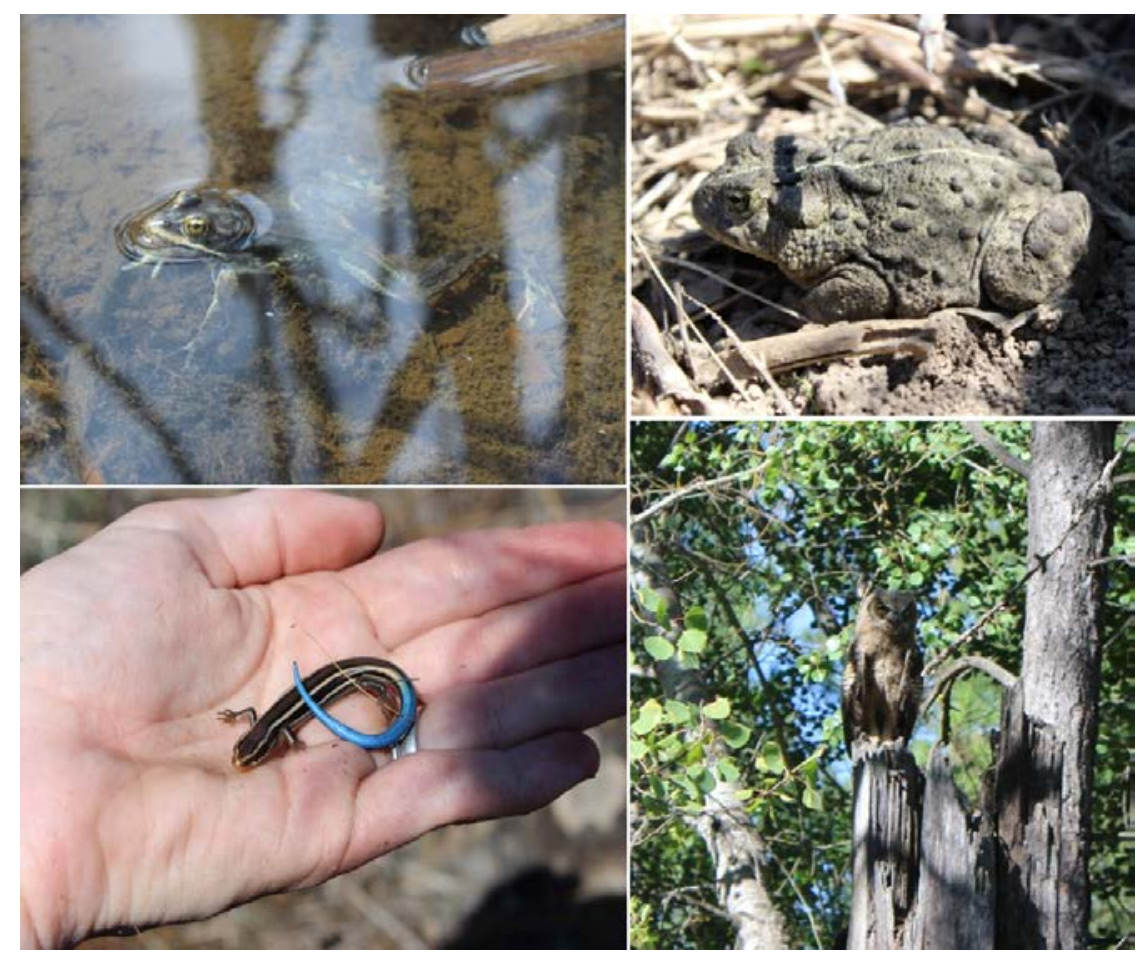


The US Army Engineer Research and Development Center (ERDC) solves the nation's toughest engineering and environmental challenges. ERDC develops innovative solutions in civil and military engineering, geospatial sciences, water resources, and environmental sciences for the Army, the Department of Defense, civilian agencies, and our nation's public good. Find out more at www.erdc.usace.army.mil.

To search for other technical reports published by ERDC, visit the ERDC online library at http://acwc.sdp.sirsi.net/client/default. 


\title{
Avian and Herpetological Survey Results for Fairchild Air Force Base and Ancillary Properties
}

\author{
Jinelle H. Sperry \\ Construction Engineering Research Laboratory (CERL) \\ US Army Engineer Research and Development Center \\ 2902 Newmark Dr. \\ Champaign, IL 61822-1076
}

Final Report

Approved for public release; distribution is unlimited.

Prepared for Fairchild AFB, WA 99011 


\section{Abstract}

Many reptile, amphibian (collectively termed "herpetofauna"), and avian populations are declining at a precipitous rate. Department of Defense (DoD) installations likely serve as refuges of intact critical habitat for avian and herpetofaunal species. As more species become a conservation concern, it becomes increasingly important for DoD land managers to document the species that currently exist on their lands and, through proactive management, avoid potential conflicts between conservation measures and military training. DoD installations will likely assume the task of protecting threatened and endangered herpetofaunal species. Installation land management practices will maintain the long-term viability of these species' populations. The first step in developing a process to successfully manage wildlife species on DoD installations is to survey their populations. This work surveyed avian and herpetofaunal populations on Fairchild Air Force Base (FAFB) and used survey results to extrapolate guidelines for species management.

DISCLAIMER: The contents of this report are not to be used for advertising, publication, or promotional purposes. Citation of trade names does not constitute an official endorsement or approval of the use of such commercial products. All product names and trademarks cited are the property of their respective owners. The findings of this report are not to be construed as an official Department of the Army position unless so designated by other authorized documents. 


\section{Contents}

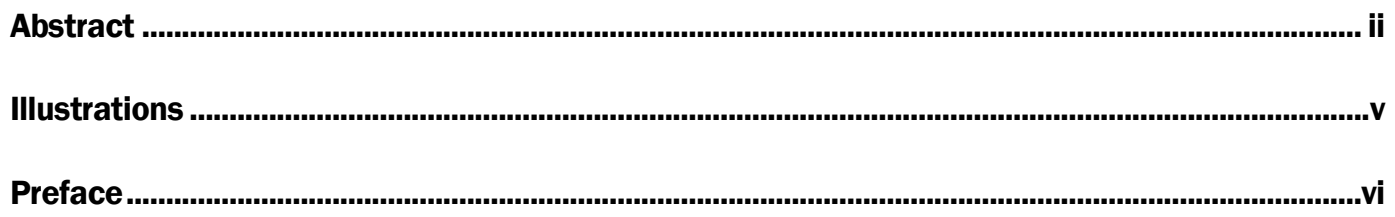

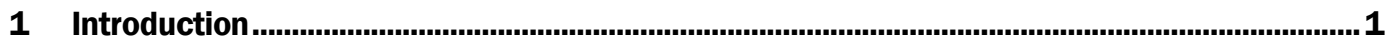

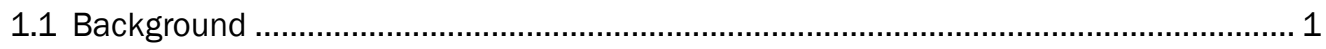

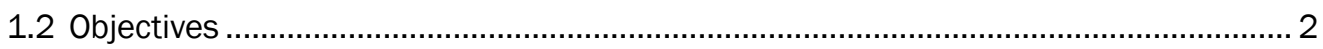

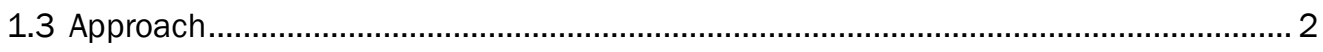

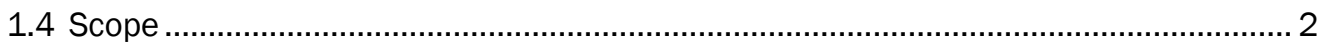

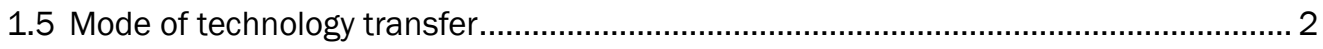

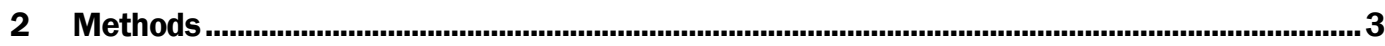

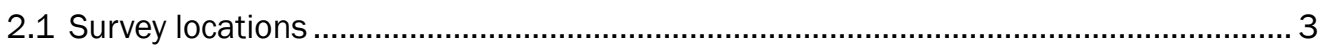

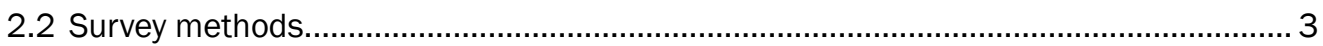

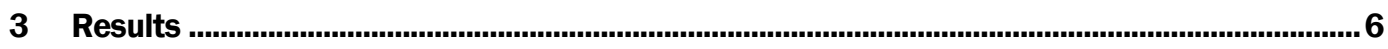

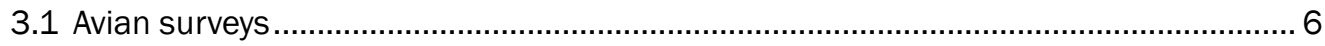

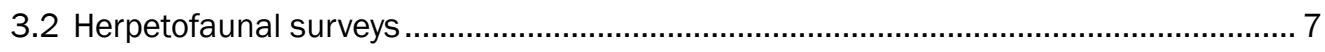

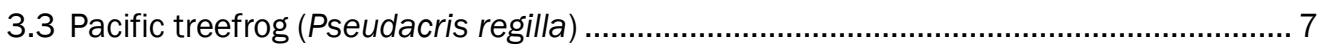

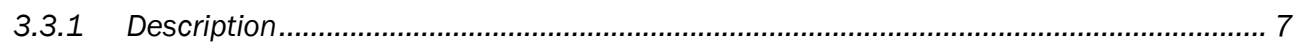

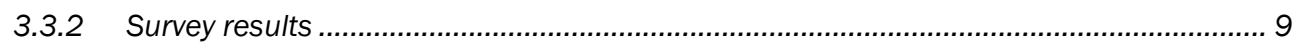

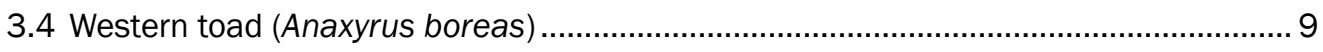

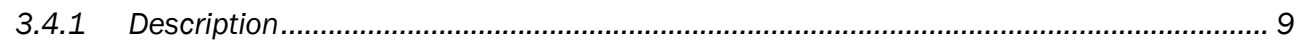

3.4.2 Survey results .............................................................................................. 9

3.5 Western terrestrial garter snake (Thamnophis elegans) .......................................... 10

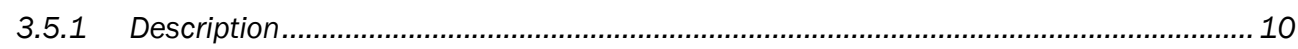

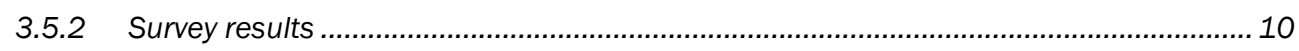

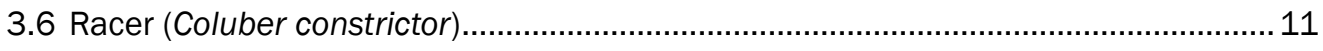

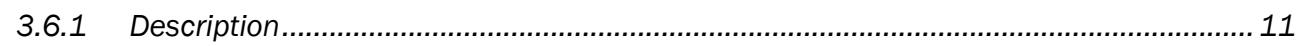

3.6.2 Survey results ................................................................................................... 12

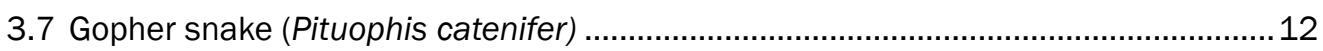

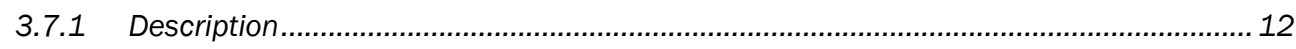

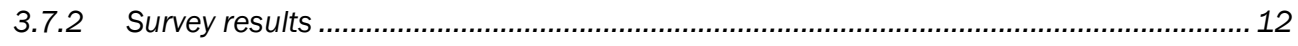

3.8 Western Skink (Eumeces skiltonianus) ............................................................... 13

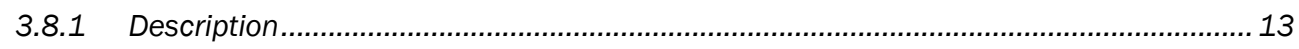

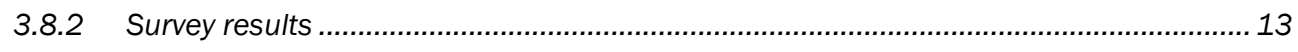

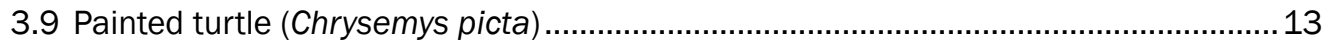

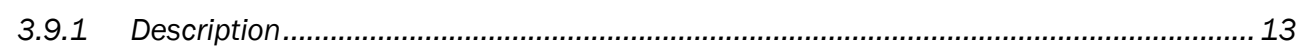

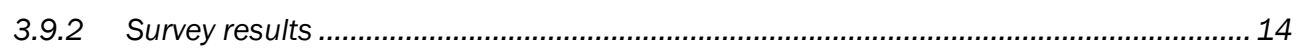


5 Conclusions and Recommendations …...................................................................

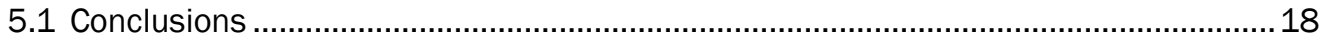

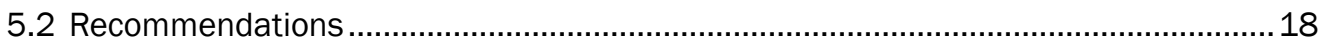

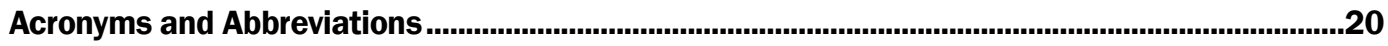

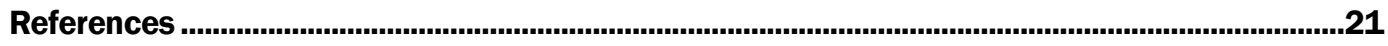

Appendix A : Point Count Locations

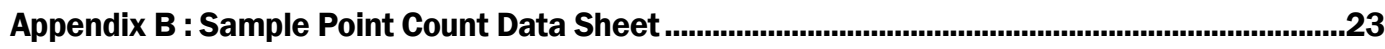

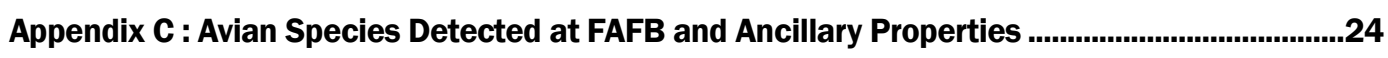

Report Documentation Page (SF 298) ....................................................................................27 


\section{Illustrations}

\section{Figures}

1 Avian and herpetological survey areas at FAFB. Light green represents forested habitats, green represents shrublands, brown represents semi-desert (scrubherb) habitats, blue represents wetland areas/vegetation, and gray indicates developed areas

2 Reptile and amphibian species detections at FAFB .......................................................... 8

3 Pacific treefrog tadpole at Clear Lake Recreation Area .......................................................... 8

$4 \quad$ Western Toad at JPRA .................................................................................................10

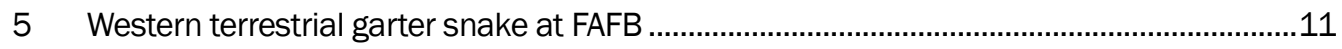

6 Racer at JPRA.............................................................................................................

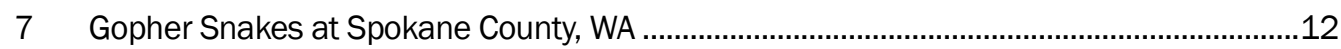

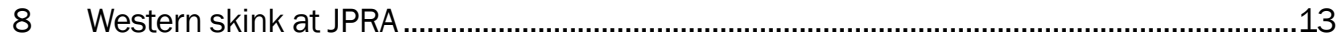

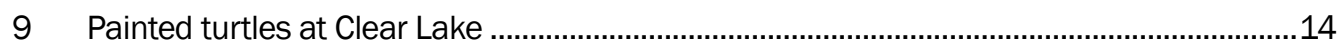

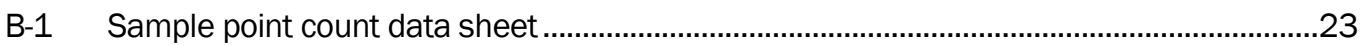

\section{Tables}

A-1 Point Count Locations at Fairchild Air Force Base, Clear Lake Recreation Area, and JPRA (listed as UTM coordinates)

C-1 Avian species detected at FAFB and ancillary properties (Clear Lake and JPRA). Column headings Wildlife and T \& E are areas within FAFB designated in Fig. 1. Column heading "Fairchild" refers to any other areas within FAFB. Listed here are all species detected, including those detected outside of standard point count surveys 


\section{Preface}

This study was conducted for Fairchild Air Force Base (FAFB) via Military Interdepartmental Purchase Request (MIPR) No. F1X3011187Go01. The technical monitor was Steven Selser, FAFB Natural and Cultural Resources Manager.

This work was conducted by the Ecological Processes Branch (CN-N), Installations Division (CN), Construction Engineering Research Laboratory (CERL), Engineer Research and Development Center (ERDC). The CERL principal investigator was Jinelle H. Sperry. William D. Meyer is Chief, CEERD-CN-N, and Michelle J. Hanson is Chief, CEERD-CN. The associated Technical Director was Alan Anderson, CEERD-CV-T. The Director of ERDC-CERL is Dr. Ilker R. Adiguzel.

CERL is an element of the US Army Engineer Research and Development Center (ERDC), US Army Corps of Engineers. The Commander and Executive Director of ERDC is COL Jeffrey R. Eckstein, and the Director of ERDC is Dr. Jeffery P. Holland. 


\section{Introduction}

\subsection{Background}

Many wildlife species are experiencing drastic population declines. Certain taxa, such as reptiles and amphibians (collectively called "herpetofauna"; Gibbons et al. 2000, Stuart et al. 2004) and certain groups of birds (e.g. grassland birds; Herkert 1994), appear to be particularly vulnerable. Many military installations serve as refuges for a large number of the nation's threatened and endangered species (TES). This is likely due to the prevalence of large swaths of undisturbed habitats on those installations.

Military installations and ranges serve as significant platforms for achieving the readiness of our military forces. These assets are used for training and testing purposes to rigorously expose troops to all the realistic threats and tactics of war. Restrictions imposed to protect TES and their critical habitat can have a detrimental impact on the military's ability to "train as we fight." Nevertheless, DoD is committed to meeting land stewardship requirements while ensuring the long-term viability and continuity of training ranges.

Effective management of wildlife species on an installation requires detailed knowledge both of what species are present and where they are present. For many installations, baseline surveys are a key component of Integrated Natural Resource Management Plans (INRMP). Survey outcome can dictate future management actions. According, a primary goal of the Fairchild Air Force Base Natural Resource Management Plan (2011) is "monitoring and inventory ... to properly assess and manage habitat and native species on the Installation."

This work was undertaken to survey herpetofaunal and avian populations on three Fairchild Air Force Base (FAFB) properties and to provide guidelines for species management. Previously conducted herpetofaunal surveys on FAFB in 2012 did not cover the ancillary properties of Clear Lake Recreation Area and Joint Personnel Recovery Agency (JPRA) sites. This report covers avian surveys that took place on all FAFB facilities and herpetofaunal surveys for Clear Lake and JPRA. 


\subsection{Objectives}

The objectives of this work were to perform surveys of avian and herpetofaunal populations on all FAFB properties, and to use the results of those surveys to provide guidelines for species management.

\subsection{Approach}

Avian and herpetofaunal surveys were conducted at FAFB, Clear Lake, and JPRA on 2-7 May, 12-18 June, and 16-19 July, 2013. Avian surveys were conducted using standard point count methodology. Herpetological survey methods included timed aural surveys, timed visual surveys, dip netting, road surveys, and cover boards. The collected data were compiled, summarized, and analyzed. Conclusions were drawn and recommendations were formulated to provide guidelines for species management.

\subsection{Scope}

Although this work focused on FAFB avian and herpetofaunal populations, the guidelines for management of these species developed from those surveys may find broader application on other similar DoD installations.

\subsection{Mode of technology transfer}

This report will be made accessible through the World Wide Web (WWW) at URL: http://libweb.erdc.usace.army.mil 


\section{Methods}

\subsection{Survey locations}

The main FAFB installation is a 4500-acre site located in Spokane County in eastern Washington State. FAFB is located in the Columbia Plateau Ecoregion (EPA; Omernik 1987) and is dominated by shrub-steppe and grassland communities. Avian and herpetological survey efforts were focused on the unimproved 1400 acres in the northeast corner and southern portion of the base. For reporting purposes, the southern portion of the installation was divided into four areas, generally based on a bow hunting areas map provided to survey personnel (Figure 1).

Clear Lake Recreation Area is a 34-acre facility located along the shoreline of Clear Lake, a 315-acre lake. Approximately half of the site is comprised of open and landscaped areas with developed beaches, picnic areas, parking areas, cabins, and boat docks. The other half of the site is comprised of Ponderosa Pine forests with a tent campground area close to the shore. A small wetland/pond is present on the western edge of the site.

JPRA is an upland site comprised primarily of Ponderosa Pine forests and shrub-steppe habitats. Many buildings and associated developed/landscaped areas are scattered throughout the site. The site contains a series of basalt outcroppings with numerous exposed rocks and rock piles. There are no permanent wetlands or water bodies on the site.

\subsection{Survey methods}

Avian surveys were conducted 2-5 May, 12 - 18 June, and 15-17 July 2013. The surveys were timed to coincide with early, peak, and late breeding efforts. Point counts, evenly spaced across all sites (Appendix A), encompass all major habitat types. Point counts were initiated within 30 minutes of sunrise and were completed within 5 hours. Each point was surveyed for 10 minutes. At each point, the following data were collected for each bird detected: species, distance from point, time interval (time since arriving at point), mode of detection (song, call, visual, or fly-over), and gender (if determinable). Appendix B contains a sample datasheet. 
Herpetofaunal surveys were conducted at FAFB on 2-7 May, 12-18 June, and 16-19 July 2013. The surveys were timed to coincide with amphibian mate calling, free swimming larvae, and metamorph emergence, respectively. General survey methods included timed aural surveys, timed visual surveys, dip netting, road surveys, and cover boards. Survey methods followed protocols outlined in Heyer et al. (1994). To survey for amphibian mate calling, timed aural surveys were conducted approximately 1 hour before and 2 hours after sunset. Aural surveys were primarily conducted during the May survey. In most cases, researchers surveyed breeding areas on foot and made regular stops to listen for calls.

Figure 1. Avian and herpetological survey areas at FAFB. Light green represents forested habitats, green represents shrublands, brown represents semi-desert (scrub-herb) habitats, blue represents wetland areas/vegetation, and gray indicates developed areas.

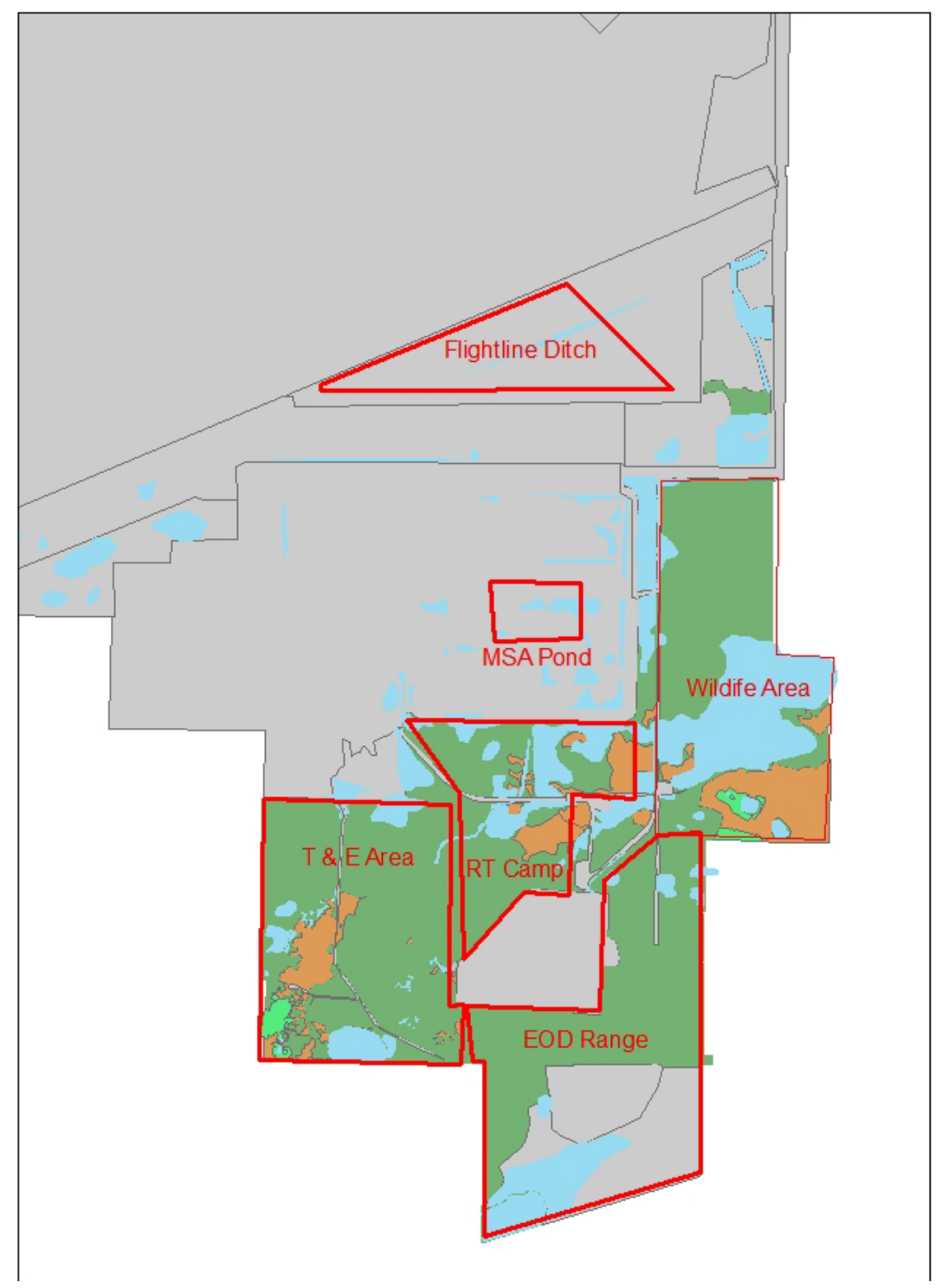


Timed visual surveys were conducted during daylight hours. Timing of survey varied depending on survey date and ambient temperature. Visual surveys focused on amphibian breeding areas and included surveys for adults, larvae, and/or eggs. Attempts were made to identify and handcapture all individuals. Road surveys were conducted in the hours around sunset and during heavy precipitation. Road surveys focused on paved roads to maximize opportunity to detect basking herpetofauna.

Dip netting was conducted in ponds during the June survey to capture larval amphibians. Sweeps were attempted at a variety of pond depths. All captured larvae were documented and species were identified. 


\section{Results}

\subsection{Avian surveys}

A total of 106 avian species were detected across the three FAFB sites, including opportunistic detections (Appendix C). Point count surveys detected 93 species. Clear Lake had the highest species richness with 14.36 $( \pm 0.81)$ species detected per point, followed by FAFB with $8.98( \pm 0.39)$ species/point and JPRA with $8.33( \pm 0.48)$ species/point. The most common species detected at Clear Lake was the Brewer's Blackbird (Euphagus cyanocephalus) with 151 detections. The most common species at JPRA was the American Robin (Turdus migratorius) with 85 detections. The most common species at FAFB was the Yellow-headed Blackbird (Xanthocephalus xanthocephalus) with 88 detections.

Some species, such as American Robin, Killdeer (Charadrius vociferous) and Western Wood Pewee (Contopus sordidulus) were detected frequently at all sites. As one might expect, water-associated birds, such as American Coot (Fulica americana), Double-crested Cormorant (Phalacrocorax auritus), and Pied-billed Grebe (Podilymbus podiceps) were detected only at Clear Lake. JPRA had exclusively upland birds with widespread detections of Cedar Waxwings (Bombycilla cedrorum), Chipping Sparrows (Spizella passerine), Say's Phoebe (Sayornis saya) and Mountain Chickadee (Poecile gambeli). FAFB, with its mix of wetland and upland habitats, had a wide range of bird species including some wetland-associated birds, such as Sora (Porzana carolina) and Wilson's Snipe (Gallinago gallinago), as well as upland species such as Western Meadowlark (Sturnella neglecta) and Savannah Sparrow (Passerculus sandwichensis).

Three species of conservation concern were detected at the sites. Two Northern Goshawks (Accipiter gentilis), a Washington State Candidate Species, were detected. One was seen during the May survey at Clear Lake and the other during the June survey near the hunter's blind in the Wildlife Area. A Common Loon (Gavia immer) and a Bald Eagle (Haliaeetus leucocephalus), both Washington State Sensitive Species, were detected at Clear Lake during the May survey.

Many other species that were detected on the sites, including Savannah Sparrow and Grasshopper Sparrow, have experienced drastic population 
declines throughout their range (Herkert 1994) and are currently on conservation "watch lists" such as the State of the Birds" and Audubon Watchlist. ${ }^{+}$The highest abundance of birds was found at Clear Lake with an average of $42.71( \pm 5.51)$ birds detected per point, followed by FAFB with 21.68 birds/point $( \pm 1.54)$ and JPRA with $19.42( \pm 1.78)$ birds/point.

\subsection{Herpetofaunal surveys}

Herpetofaunal diversity on the main FAFB installation was very similar in 2013 to what was recorded in 2012 (Figure 2). Although wetland water levels were much reduced as compared with 2013, amphibian breeding was still documented in the Wildlife Areas (Pacific Treefrogs) and Flightline Ditch (Columbia Spotted Frogs). Similar to 2012, the most common species detected were Pacific Treefrogs, Columbia Spotted Frogs, and Western terrestrial garter snakes. Other species detected included the Valley Garter Snake and Long-toed Salamander. Because of the likely redundancy with the 2012 report, survey results detailed below will focus on Clear Lake and JPRA.

Seven species, two amphibian and five reptilian, were documented at the sites. One of the species detected, the Western Toad is a Washington State Candidate Species. The following sections detail information on detections of each species. Unless otherwise noted, all species information was obtained from the Washington Herp Atlas (Hallock and McAllister 2005) or NatureServe Explorer (www.natureserve.org).

\subsection{Pacific treefrog (Pseudacris regilla)}

\subsubsection{Description}

The Pacific Treefrog is a small $(<5 \mathrm{~cm})$ frog from the family Hylidae. It is easily identified by its conspicuous dark facial mask that extends from the nose, through the eye and tympanum, to the shoulder (Figure 3). Adults have relatively smooth skin and a dorsal body color of green to brown. Blotches or stripes frequently occur on the back of the head and down the back. Ventral surface is typically white with yellow coloration on the legs. Tree frog tadpoles are identified by prominent eyes on the margins of the head that appear to be on the side of the head when viewed from above.

\footnotetext{
* http://www.stateofthebirds.org/

† http://birds.audubon.org/2007-audubon-watchlist
} 
Figure 2. Reptile and amphibian species detections at FAFB.

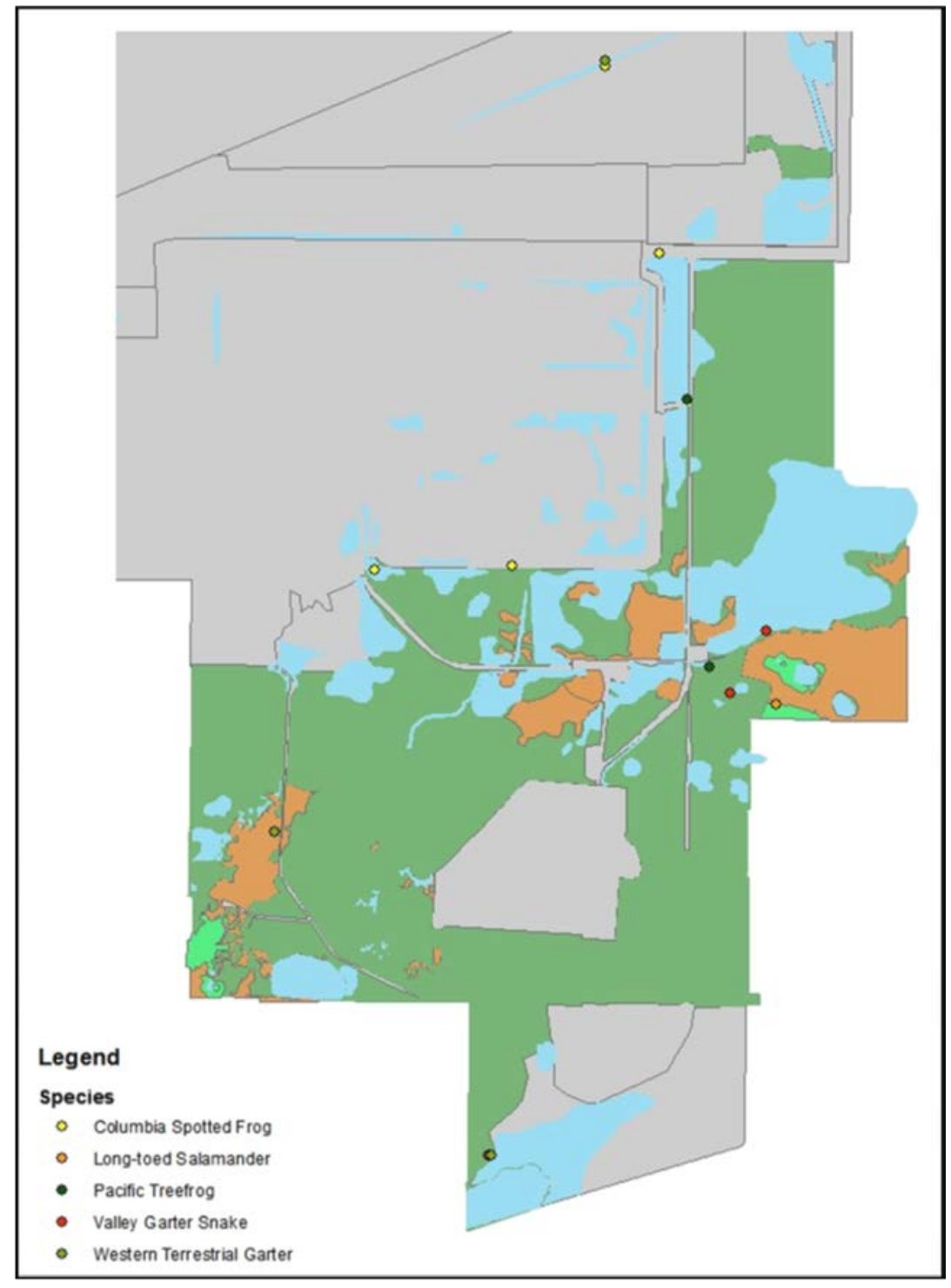

Figure 3. Pacific treefrog tadpole at Clear Lake Recreation Area.

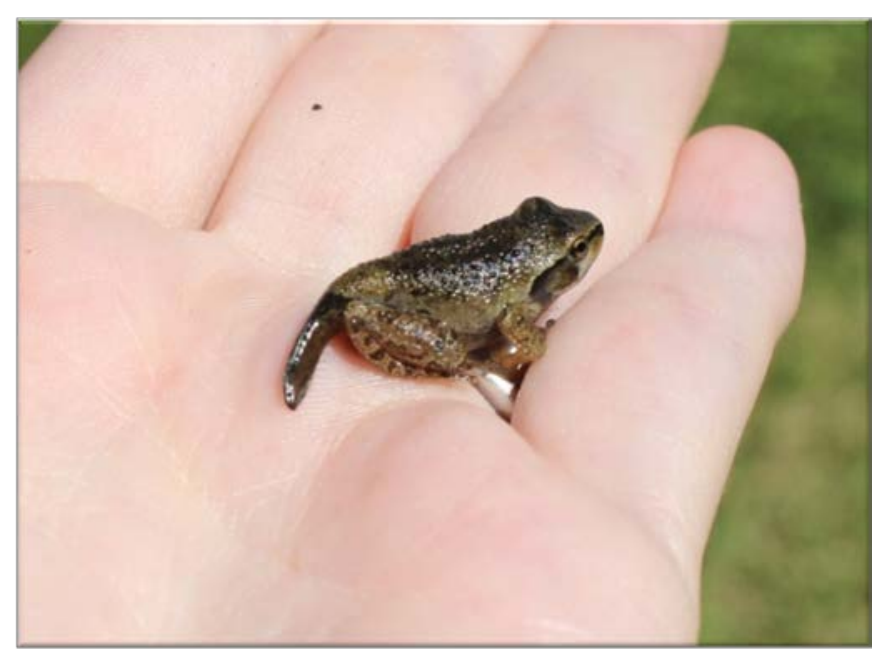


Pacific Treefrogs are found in a wide variety of habitats, including humandisturbed habitats. Pacific Treefrogs have no Federal status and are considered abundant globally (global rank = G5) and in Washington State (state rank $=\mathrm{S}_{5}$ ). Treefrogs are the most commonly seen and heard frog species in Washington State (Hallock and McAllister 2005).

\subsubsection{Survey results}

Pacific Treefrogs were detected in the pond on the western edge of the Clear Lake Recreation Area. Adults were detected during the May survey, both through timed visual surveys and aural surveys. Tadpoles were detected during the June and July surveys. Many (20+) tadpoles were detected at each survey, suggesting a fairly large breeding population. Although water levels in the pond dropped significantly over the course of the survey period, metamorphs were detected in small remaining pools of water during the July survey, indicating successful recruitment.

\subsection{Western toad (Anaxyrus boreas)}

\subsubsection{Description}

The Western Toad is a medium- to large-size toad (5.1-12.7 cm SVL) with varied dorsal coloring (usually brown or green) and "warts" on skin. Western Toads have prominent parotoid glands on the head, posterior to the eyes. Pupil is horizontally oval. A distinguishing characteristic for this species is a distinct, thin, light middorsal stripe (Figure 4).

Adult Western Toads are primarily terrestrial and are found in a variety of habitats including prairies, forests, and canyon grasslands. Breeding habitats are usually permanent water bodies including wetlands, ponds, lakes, reservoirs and off-channel habitats of rivers.

Western Toads are a Washington State Candidate species due to recent declines in the Puget Trough and lower Columbia River area. Many populations previously occurring in these areas are now extirpated.

\subsubsection{Survey results}

A Western Toad was detected during the May survey (7 May 2013) at JPRA (UTM 456900 5283495) under a piece of plywood associated with a large refuse pile, consisting of metal sheeting, plywood, and hay bales. 
Figure 4. Western Toad at JPRA.

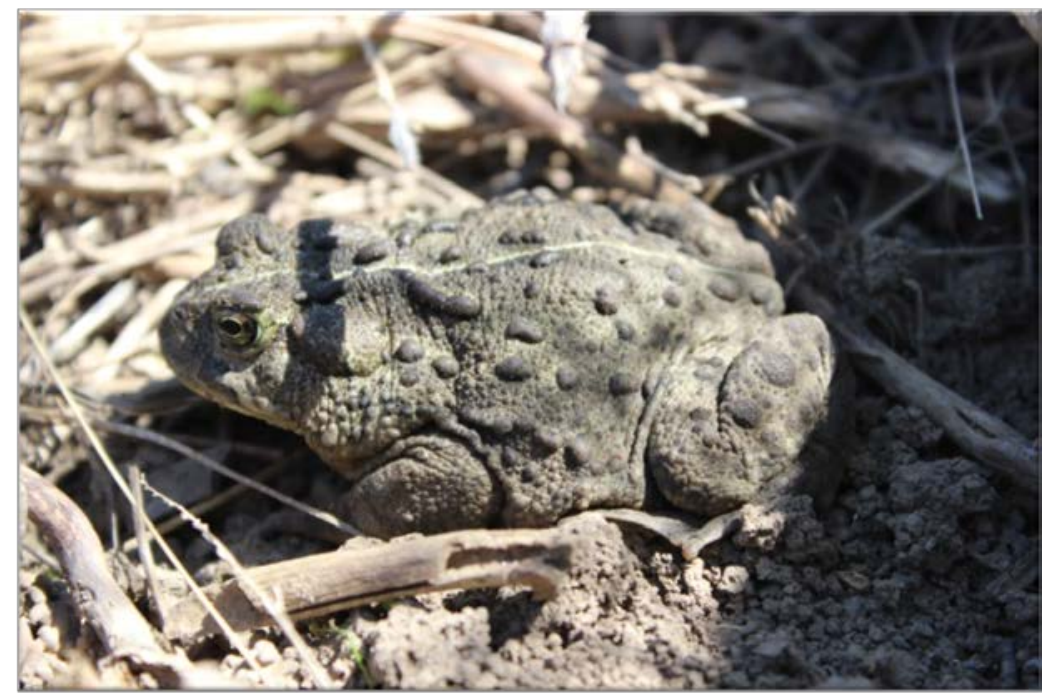

\subsection{Western terrestrial garter snake (Thamnophis elegans)}

\subsubsection{Description}

The Western terrestrial garter snake is a medium-size snake (max $97 \mathrm{~cm}$ length) identified by three yellow or cream colored lateral stripes on a dorsal background color of gray to brown (Figure 5). Small dark spots often occur in alternating rows between the vertebral and lateral stripes. Coloration can be variable making differentiation between garter snake species difficult. Consultation of a field guide is recommended.

In Washington State, Western terrestrial garter snakes are most often found around water sources, including ponds, lakes, streams, and rivers (Hallock and McAllister 2009). They are typically found in grass or shrubby open areas on edges of water bodies (Hallock and McAllister 2009). T. elegans is a common, wide-ranging species and currently has no Federal or state conservation status.

\subsubsection{Survey results}

Western terrestrial garter snakes were detected both at JPRA and Clear Lake. The individual at Clear Lake was found swimming through the pond on the western edge of the installation. The individual at JPRA was found in a grassland area. 
Figure 5. Western terrestrial garter snake at FAFB.

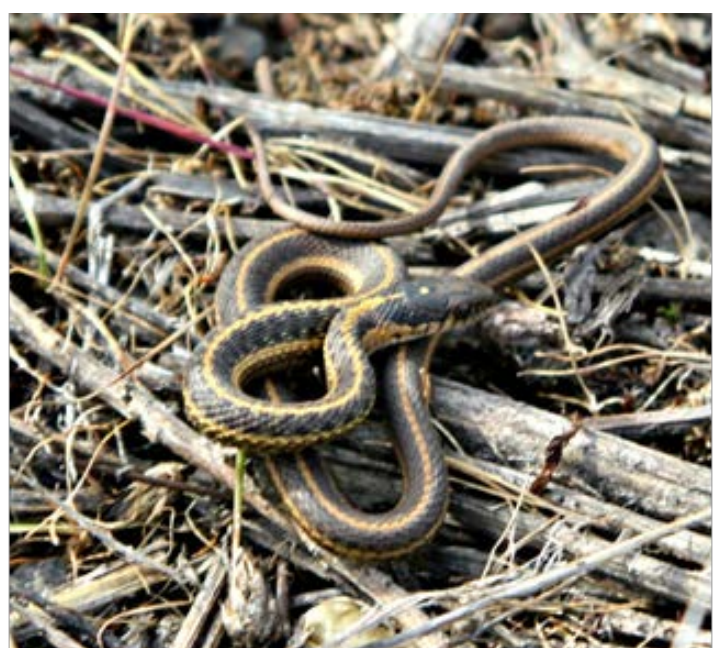

\subsection{Racer (Coluber constrictor)}

\subsubsection{Description}

Racers are medium- to large-size (max $190 \mathrm{~cm}$ length) colubrids with smooth (unkeeled) scales and a solid dorsal coloring of brown to olive (Figure 6). Ventral coloring can range from yellow to cream. Racers are very alert, agile snakes that typically flee when encountered. They will raise their heads above ground to survey surroundings.

Racers are found in a wide variety of habitats including forests, open areas, and habitat edges. When inactive, racers will hide underground or under surface cover. Racers are widespread and abundant and so have no state or Federal conservation status.

Figure 6. Racer at JPRA.

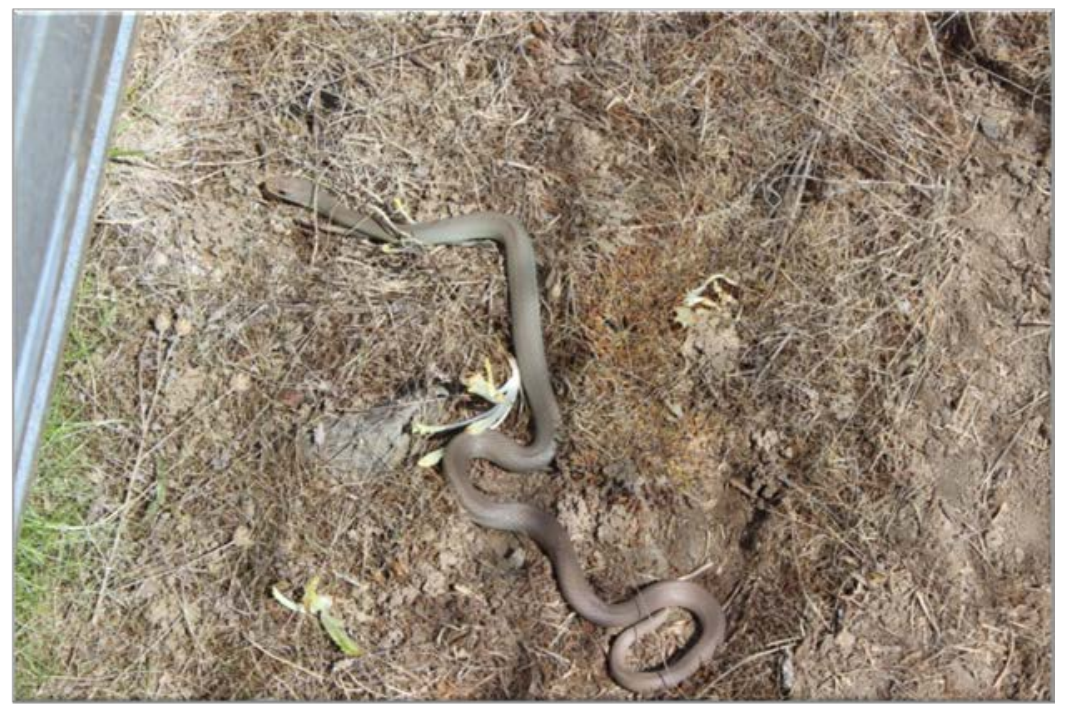




\subsubsection{Survey results}

Two racers were detected during the May survey at JPRA. One Racer was found under a piece of metal sheeting associated with a refuse pile and the other in a grassland area.

\subsection{Gopher snake (Pituophis catenifer)}

\subsubsection{Description}

The gopher snake, also referred to as "bullsnake," is a large (180 cm SVL) snake with dark blotches on a beige or tan dorsal background and a distinct eye stripe (Figure 7). Blotches are typically large and square-shaped on the dorsal surface and smaller on the sides. A small, dark "tear" marking occurs below each eye.

Gopher snakes are associated with dry habitat types such as shrub-steppe and Ponderosa Pine forests. They can be diurnal or nocturnal, but spend most of their time below the ground surface in animal burrows. Gopher snakes exhibit dramatic defense behaviors (hissing, puffing the body, coiling, striking), but are not venomous. Gopher snakes are common and widespread in eastern Washington.

\subsubsection{Survey results}

A gopher snake was detected during the July survey at JPRA on top of a rock outcropping. JPRA personnel indicated that gopher snakes are regularly found around the installation and that they are often associated with man-made structures (underground piping) in the winter months.

Figure 7. Gopher Snakes at Spokane County, WA.

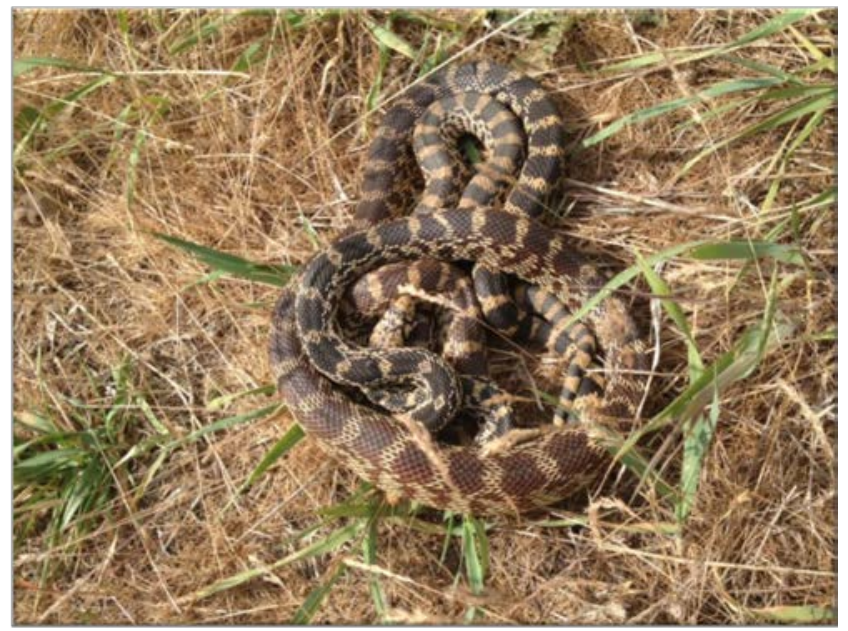




\subsection{Western Skink (Eumeces skiltonianus)}

\subsubsection{Description}

The Western Skink is a small (5.4 - 8.6 cm SVL), slender lizard with a distinctive middorsal stripe and long, bright blue tail (Figure 8). The bright blue tail can fade with age.

Western Skinks are typically very secretive, but can be found in a variety of habitats including dry open forests, shrub-steppe, and grassland. Western Skinks are typically found by turning rocks or woody debris. They are diurnal and very fast moving. Western Skinks are widespread and common, and have no state or Federal conservation status.

\subsubsection{Survey results}

A Western Skink was found during the May survey at JPRA. The skink was found under a rock on top of a rock outcropping. Clear Lake personnel indicated that Western Skinks have been detected near the outbuildings at the site, but none were detected during the course of this survey.

Figure 8. Western skink at JPRA.

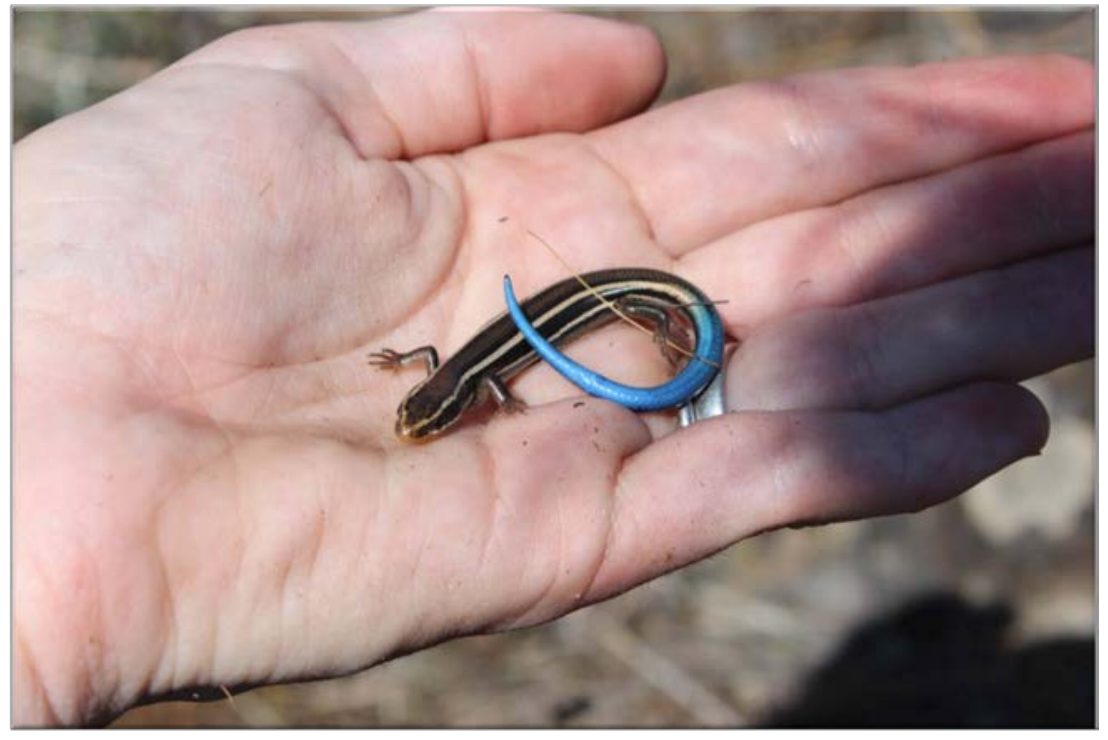

\subsection{Painted turtle (Chrysemys picta)}

\subsubsection{Description}

The Painted turtle is a medium-size aquatic turtle with a dark olive, brown or black carapace, yellow streaking on head, and bright red markings on plastron. Coloration of the plastron fades with age. This species is found 
primarily in aquatic habitats. It prefers habitats with muddy sediment and abundant aquatic vegetation. Aquatic habitats include lakes, ponds, wetlands, and slow flowing areas of rivers. Individuals are often detected with heads emerging from water and will often submerge under water when approached. This species is common and widespread with no state or Federal conservation status.

\subsubsection{Survey results}

Numerous (20+) Painted turtles were detected at Clear Lake with detections at each survey period. Turtles were primarily seen swimming in the lake, but were also detected in large numbers on partially submerged wood planks near the fishing dock (Figure 9). Two turtles were detected on the hillsides overlooking the lake.

Figure 9. Painted turtles at Clear Lake.

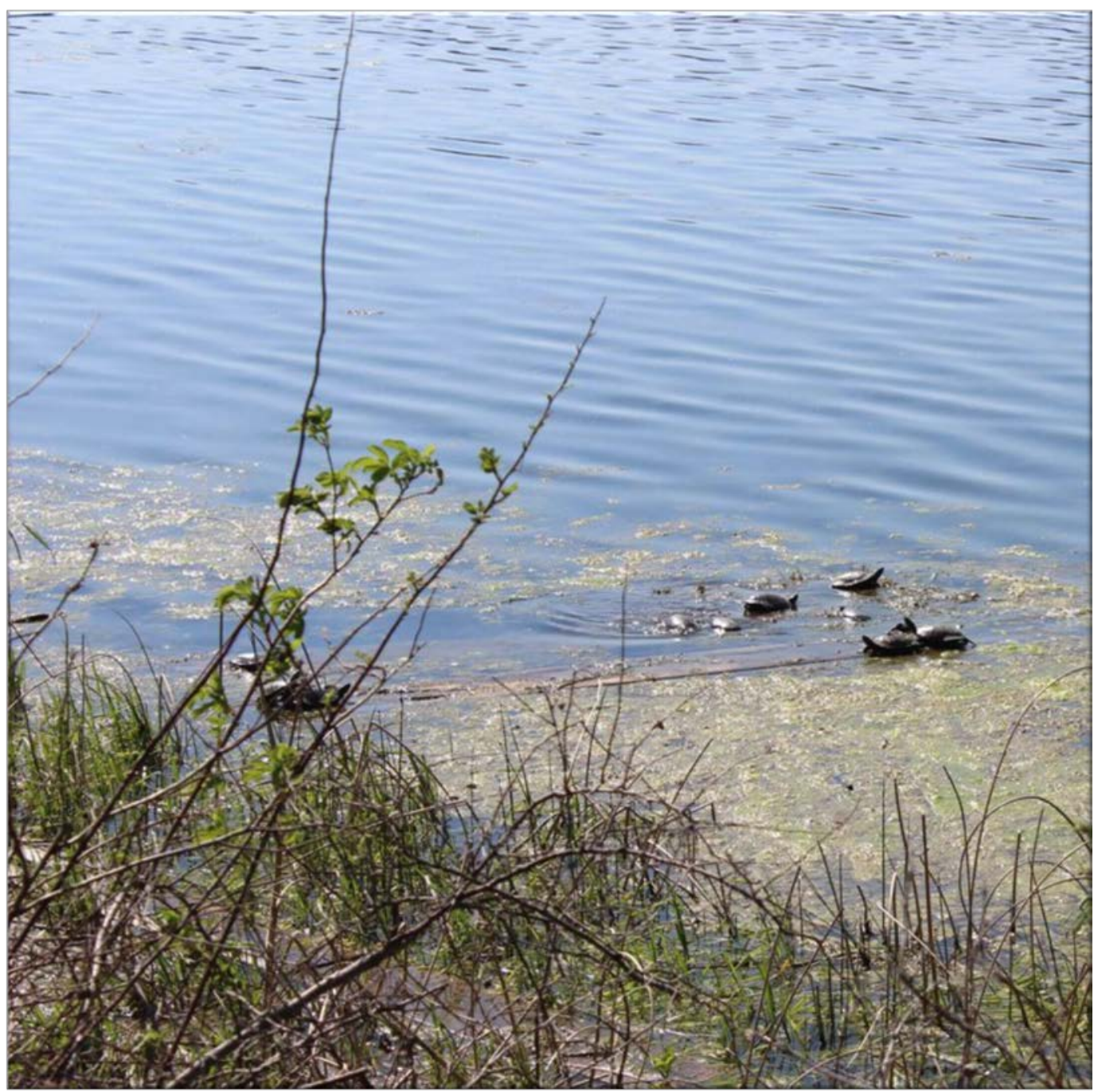




\section{Discussion}

Avian and herpetological surveys at FAFB, Clear Lake Recreation Area, and JPRA revealed high species diversity of both taxa on the sites. Between 2012 and 2013 surveys, 11 herpetofaunal species were documented on the sites. The 2013 avian surveys documented 106 species, including a diverse mix of aquatic-associated and upland species.

Avian species richness and abundance was highest at the Clear Lake Recreation Area. This likely reflects the diversity of habitats at the site including the lake itself, wetland habitats, and upland habitats. All of the species of conservation concern that were detected during the survey (Common Loon, Northern Goshawk, and Bald Eagle) were detected at the Clear Lake site. Although further monitoring/surveys may be warranted, it is likely that the individuals detected at the Clear Lake site use additional areas within/along the lake, outside of the purview of FAFB management. All of the species were only detected once and all were detected only during the May survey.

Overall, avian species richness and abundance was similar between the main FAFB installation and JPRA, although species composition differed somewhat. FAFB had a large number of wetland species such as Sora and Wilson's Snipe, as one might expect considering the numerous wetlands on the site. These species were not present on JPRA. One of the Washington State Sensitive Species, the Northern Goshawk, was detected in the Wildlife Area at FAFB. Several of the upland species detected at FAFB, such as Grasshopper Sparrow and Savannah Sparrow, are declining in numbers across their range (Heskert 1994). The Grasshopper Sparrow was widespread in the T\&E area of FAFB and the Savannah Sparrow was widespread both in the Wildlife and T\&E areas. JPRA species were exclusively upland species and included larger numbers of species such as Chipping Sparrow and Say's Phoebe than were found at the two other sites.

Reptile and amphibian species detected at Clear Lake and JPRA were similar to those detected at FAFB during the 2012 survey, with some notable exceptions. Similarities include a large number of Pacific Treefrogs detected both at FAFB and Clear Lake. At both sites, Pacific Treefrogs were associated with ponds/wetlands and both adults and tadpoles were detected. The pond at the western edge of Clear Lake appeared to have large 
numbers of tadpoles (20+ detected during each visit) and the July survey detected both tadpoles and metamorphs. Breeding attempts were likely less successful at FAFB in 2013 due to lack of standing water. Although early stage tadpoles were detected in a pond in the Wildlife Area during the May survey, that area did not have any standing water during the June survey. In fact, nearly all of the ponds in the Wildlife Area had no water by the July survey. Other similarities included detections of Western terrestrial garter snakes at all sites.

The most obvious difference between the sites was the lack of detections of Columbia Spotted Frogs at either ancillary property. This is likely due to lack of suitable habitat on those sites. Columbia Spotted Frogs were one of the most commonly detected species at FAFB during both the 2012 and 2013 survey efforts. They were most often associated with free flowing streams on FAFB. Although water levels were greatly reduced on FAFB in 2013, large numbers of adults and tadpole Columbia Spotted Frogs were detected in the flightline ditch. In 2012, tadpoles were detected primarily along the stretches of ditch with emergent vegetation. In 2013, that pattern was reversed. Tadpoles were almost exclusively found associated with floating algae in the more open, deeper pools of water. Similar to 2012, metamorphs were found in the pond at UTM 451650 5272683, although in much reduced numbers.

Three species of herpetofauna were detected at Clear Lake Recreation Area: Pacific Treefrogs (see above), Western terrestrial garter snake, and Painted turtles. Painted turtles were primarily detected in the vegetated area on the western point of the lake and basking on floating wood near the fishing docks (10+ individuals at one time). They were also detected swimming in open water $>10 \mathrm{~m}$ offshore as well as on the hillsides overlooking the lake. In addition to the three species detected during the survey, Clear Lake personnel indicate that Western Skinks are often present near the recreational buildings.

Although survey times were limited due to logistic/security concerns, JPRA appears to have a high diversity of herpetofaunal species. Five species were detected on the site, including the Racer, Western terrestrial garter snake, Gopher Snake, Western Skink, and Western Toad. Two of the species, the Western Skink and Western Toad, were not detected on the other two sites. One of the species, the Western Toad is a Washington State Candidate Species. Many of the detections were associated either 
with the rock outcroppings on the site or with refuse piles. These structures likely serve as retreat sites. Although only one gopher snake was detected, JRPA personnel indicate that gopher snakes are regularly detected on the site, primarily during the winter months in association with recessed piping. JPRA personnel also indicated that Western Rattlesnakes had been detected on the site, although not in recent years. 


\section{Conclusions and Recommendations}

\subsection{Conclusions}

This work surveyed avian and herpetofaunal populations on FAFB, Clear Lake Recreation Area, and JPRA. Survey results indicate high diversity of both taxa with 106 bird species and 11 herpetofaunal species detected among the sites. Clear Lake Recreation Area had the highest avian diversity and abundances, likely resulting from the wide range of habitats present on that site. FAFB and JPRA had similar avian diversity and abundances although species composition differed. FAFB housed wetland-associated species and JPRA contained exclusively upland species. Three species of conservation concern (the Common Loon, Northern Goshawk, and Bald Eagle) were detected on the sites. In addition, numerous species that have experienced range wide population declines were also detected.

Of herpetofauna, Columbia Spotted Frogs, Pacific Treefrogs, Western terrestrial garter snakes, and Painted turtles were the most commonly detected species, although species composition varied among sites. Other species detected include the Racer, Valley Garter Snake, Long-toed Salamander, Western Skink, and Western Toad. Two of the species detected, the Columbia Spotted Frog and Western Toad, are Washington State Candidate Species. The Columbia Spotted Frog was detected in large numbers on FAFB, indicating strong populations. Only one Western Toad was detected, but given the cryptic nature of toads, it is difficult to make any assertion regarding population status on the sites.

\subsection{Recommendations}

Due to the large number of species of conservation concern detected during the surveys, it is recommended that FAFB Natural Resource personnel consider resurveying for avian and herpetofaunal species in future years. Many of these species are experiencing population declines across their range. Multiyear information on where/when these species are found on the installation can be critical for effective management.

The use of the installations by these sensitive species likely reflects the high quality habitats present on the sites. Continued efforts to improve and/or preserve these habitats would be recommended. This is particular- 
ly true for the grassland associated species, such as the Grasshopper and Savannah Sparrow, which are experiencing population declines elsewhere across their range, but which were found relatively frequently in the habitats associated with the Wildlife and T\&E areas on FAFB. These two species, in particular, have been shown to be sensitive to invasive plant species (Schieman et al. 2003) and so continued efforts aimed at invasive species management would be recommended.

A single Western Toad, a Washington State Candidate Species, was detected at JPRA in association with a refuse pile. Additional surveys would be required to determine the extent of this species' presence on FAFB sites. Given that JPRA has no permanent bodies of water, this area is likely only used as an upland, non-breeding area. Numerous refuse piles were scattered around the site. It is likely that herpetofaunal species use many of these structures. It is recommended that caution be used when either creating or disposing of these piles to avoid potential harming sensitive reptile or amphibian species. 


\section{Acronyms and Abbreviations}

$\begin{array}{ll}\text { Term } & \text { Definition } \\ \text { ANSI } & \text { American National Standards Institute } \\ \text { CEERD } & \text { US Army Corps of Engineers, Engineer Research and Development Center } \\ \text { CERL } & \text { Construction Engineering Research Laboratory } \\ \text { DOA } & \text { Dead on Arrival } \\ \text { EOD } & \text { Explosive Ordnance Disposal } \\ \text { EPA } & \text { Environmental Protection Agency } \\ \text { ERDC } & \text { Engineer Research and Development Center } \\ \text { FAFB } & \text { Fairchild Air Force Base } \\ \text { INRMP } & \text { Integrated Natural Resources Management Plans } \\ \text { ISE } & \text { Installation Support Directorate, Environmental Division } \\ \text { IUCN } & \text { International Union for Conservation of Nature and Natural Resources } \\ \text { JPRA } & \text { Joint Personnel Recovery Agency } \\ \text { MSA } & \text { Munitions Storage Area } \\ \text { NSN } & \text { National Supply Number } \\ \text { OACSIM } & \text { Office of the Assistant Chief of Staff for Installation Management } \\ \text { OMB } & \text { Office of Management and Budget } \\ \text { RT } & \text { Reserve Training } \\ \text { SAR } & \text { Same As Report } \\ \text { SF } & \text { Standard Form } \\ \text { TES } & \text { Threatened and Endangered Species } \\ \text { TR } & \text { Technical Report } \\ \text { US } & \text { United States } \\ \text { USA } & \text { United States of America } \\ \text { USDA } & \text { US Department of Agriculture } \\ \text { USFWS } & \text { US Fish and Wildlife Service } \\ \text { UTM } & \text { Universal Transverse Mercator } \\ \text { WWW } & \text { World Wide Web } \\ & \end{array}$




\section{References}

Cushman, K. A., and C. A. Pearl. 2007. A conservation assessment for the Oregon Spotted Frog (Rana pretiosa). USDA Forest Service Region 6 Report.

Fairchild Air Force Base (FAFB). May 2011. Integrated Natural Resources Management Plan Update: Official Draft. Fairchild Air Force Base, WA: Air Mobility Command, $92^{\text {nd }}$ Wing, http://www.fairchild.af.mil/shared/media/document/AFD-110608-031.pdf

Gibbons, J. W., D. E. Scott, T. J. Ryan, K. A. Buhlman, T. D. Tuberville, B. S. Mettis, J. L. Greene, T. Mills, Y. Leiden, S. Poppy, and C. T. Winne. 2000. The global decline of reptiles, déjà vu amphibians. BioScience. 50:653-666

Hallock, L. A., and K. R. McAllister. 2005. Washington Herp Atlas. Website, http://www1.dnr.wa.gov/nhp/refdesk/herp/

Herkert, J.R. 1994. The effects of habitat fragmentation on Midwestern grassland bird communities. Ecological Applications 4: 461-471.

Heyer, W. R., M. A. Donnelly, R. W. McDiarmid, L. C. Hayek, and M. S. Foster. 1994. Measuring and monitoring biological diversity: Standard methods for amphibians. Washington, DC: Smithsonian Institute Press.

International Union for Conservation of Nature and Natural Resources (IUCN). 2011. IUCN red list of threatened species. Version 2011.2, www.iucnredlist.org

McAllister, K. R., and W. P. Leonard. 1997. Washington state status report for the Oregon Spotted Frog. Olympia, WA: Washington Department of Fish and Wildlife.

Omernik, J. M. 1987. Ecoregions of the conterminous United States. Map (scale 1:7,500,000). Annals of the Association of American Geographers 77(1):118-125.

Sas, I., S. Covaciu-Marcov, E. Kovacs, N. Radu, A. Toth, and A. Popa. 2006. The populations of Rana arvalis Nills. 1842 from the Ier Valley (The Western Plain, Romania): Present and future. Northwestern J ournal of Zoology 2:1-16.

Scheiman, D. M., E. K. Bollinger, D. H. Johnson. 2003. Effects of leafy spurge infestation on grassland birds. J ournal of Wildlife Management 67:115-121.

Stebbins, R. C. 2003. A field guide to western amphibians and reptiles. 3d ed. Boston, MA: Houghton Mifflin Company.

Stuart, S., J. S. Chanson, N. A. Cox, B. E. Young, A. S. L. Rodrigues, D. L. Fishman, and R. W. Waller. 2004. Status and trends of amphibian declines and extinctions worldwide. Science 306:1783-1786.

NatureServe. 2012. NatureServe Explorer. Website, www.natureserve.org 


\section{Appendix A: Point Count Locations}

Table A-1. Point Count Locations at Fairchild Air Force Base, Clear Lake Recreation Area, and JPRA (listed as UTM coordinates).

\begin{tabular}{|l|l|l|}
\hline Point & UTM N & \multicolumn{1}{|c|}{ UTM E } \\
\hline Clear Lake 1 & 5263297 & 447925 \\
\hline Clear Lake 2 & 5263094 & 447861.1 \\
\hline Clear Lake 3 & 5262919 & 447918 \\
\hline Clear Lake 4 & 5262838 & 447731.1 \\
\hline Clear Lake 5 & 5262701 & 447876.9 \\
\hline JPRA 1 & 5283280 & 456325.1 \\
\hline JPRA 2 & 5283511 & 456354 \\
\hline JPRA 3 & 5283588 & 456603.8 \\
\hline JPRA 4 & 5283572 & 456833.7 \\
\hline JPRA 5 & 5283279 & 456534.1 \\
\hline JPRA 6 & 5283292 & 456812 \\
\hline JPRA 7 & 5283548 & 457065.1 \\
\hline JPRA 8 & 5283283 & 457045 \\
\hline T\&E 1 & 5271548 & 451206 \\
\hline T\&E 2 & 5271536 & 451454 \\
\hline T\&E 3 & 5271524 & 451702.1 \\
\hline T\&E 4 & 5271780 & 451704 \\
\hline T\&E 5 & 5271794 & 451465 \\
\hline T\&E 6 & 5271784 & 451212 \\
\hline T\&E 7 & 5272036 & 451210 \\
\hline T\&E 8 & 5272030 & 451481.8 \\
\hline T\&E 9 & 5272019 & 451709 \\
\hline Wildlife 1 & 5272379 & 452577.1 \\
\hline Wildlife 2 & 5272386 & 452806 \\
\hline Wildlife 3 & 5272378 & 453066.1 \\
\hline Wildlife 4 & 5272641 & 453087.7 \\
\hline Wildlife 5 & 5272662 & 452820.6 \\
\hline Wildlife 6 & 5272630 & 452583 \\
\hline Wildlife 7 & 5272878 & 452583 \\
\hline Wildlife 8 & 5272886 & 452838.1 \\
\hline Wildlife 9 & 5272883 & 453097.5 \\
\hline Fairchild 1 & 5276141 & 452052 \\
\hline Fairchild 2 & 5275910 & 452014 \\
\hline & & \\
\hline
\end{tabular}




\section{Appendix B: Sample Point Count Data Sheet}

Figure B-1. Sample point count data sheet.

Fairchild AFB Point Count Form

rev. $4 / 26 / 2013$

\begin{tabular}{|c|c|c|c|c|c|c|c|}
\hline Site: & \multicolumn{4}{|l|}{ Date: } & Sky: & \multicolumn{2}{|c|}{$\begin{array}{l}\text { 0-clearifew dds, 1-partly cldy, 2-cldyl } \\
\text { overcast, 3-fog, 4-drizzle, 5-showers }\end{array}$} \\
\hline Observer: & \multicolumn{4}{|c|}{ Start Time: } & Wind: & \multicolumn{2}{|c|}{$\begin{array}{l}\text { 0-smk vitcl, 1-smk drift, 2-wnd on face, 3- } \\
\text { twog cnst motion, 4-sm brch mv, 5-trs sway }\end{array}$} \\
\hline Point: & Bout: & 1 & 2 & 3 & Noise: & Dist: & Dir: \\
\hline \multicolumn{5}{|l|}{ Comments: } & \multicolumn{3}{|c|}{$\begin{array}{l}\text { Hearing: 0-not reduced, 1-barely reduced, 2-noticeably reduced, 3- } \\
\text { greatly reduced. If present, estimate distance category and record } \\
\text { bearing to source, describe source in comments (ie. operating gas } \\
\text { well, heavy equipment, loud stream) }\end{array}$} \\
\hline
\end{tabular}

\begin{tabular}{|c|c|c|c|c|c|}
\hline $\begin{array}{l}\text { Species } \\
\text { Code }\end{array}$ & Distance $(\mathrm{m})$ & Time Interval (circle) & \begin{tabular}{|c|} 
Det. \\
Type \\
S/C/N/F
\end{tabular} & $\begin{array}{c}\operatorname{Sex} \\
\mathrm{M} / \mathrm{F} / \mathrm{U} / \mathrm{J}\end{array}$ & Comments \\
\hline & & $\begin{array}{lllllllll}1 & 2 & 3 & 4 & 5 & 6 & 7 & 10\end{array}$ & & & \\
\hline & & 1234567 & & & \\
\hline & & 123456710 & & & \\
\hline & & 123456710 & & & \\
\hline & & 1234567 & & & \\
\hline & & $\begin{array}{llllllll}12 & 3 & 4 & 5 & 7 & 7\end{array}$ & & & \\
\hline & & 123456710 & & & \\
\hline & & 123456710 & & & \\
\hline & & 1234567 & & & \\
\hline & & 123456710 & & & \\
\hline & & 12334567 & & & \\
\hline & & 123456710 & & & \\
\hline & & 1234567 & & & \\
\hline & & $\begin{array}{lllllllll}12 & 3 & 4 & 5 & 6 & 7 & 10\end{array}$ & & & \\
\hline & & 123456710 & & & \\
\hline & & 123456710 & & & \\
\hline & & 123456710 & & & \\
\hline & & $\begin{array}{lllllll}12 & 34 & 5 & 6 & 7\end{array}$ & & & \\
\hline & & $\begin{array}{lllllllll}12 & 3 & 4 & 5 & 6 & 7 & 10\end{array}$ & & & \\
\hline & & 123456710 & & & \\
\hline & & 123456710 & & & \\
\hline & & 1234567 & & & \\
\hline & & 123456710 & & & \\
\hline & & $\begin{array}{llllllll}12 & 3 & 4 & 5 & 6 & 7 & 10\end{array}$ & & & \\
\hline
\end{tabular}




\section{Appendix C: Avian Species Detected at FAFB and Ancillary Properties}

Table C-1. Avian species detected at FAFB and ancillary properties (Clear Lake and JPRA). Column headings Wildlife and T \& $E$ are areas within FAFB designated in Fig. 1. Column heading "Fairchild" refers to any other areas within FAFB. Listed here are all species detected, including those detected outside of standard point count surveys.

\begin{tabular}{|c|c|c|c|c|c|}
\hline \multirow[b]{2}{*}{ Species } & Clear Lake & Wildlife & T\&E & Fairchild & JPRA \\
\hline & \multicolumn{5}{|c|}{$\mathrm{W}=$ widespread. $\mathrm{S}=$ scattered. $\mathrm{R}=$ rare $(<3)$} \\
\hline American Coot & W & & & & \\
\hline American Crow & & $\mathrm{R}$ & $\mathrm{R}$ & $\mathrm{R}$ & $\mathrm{R}$ \\
\hline American Goldfinch & $S$ & W & W & W & W \\
\hline American Kestrel & & $\mathrm{R}$ & $\mathrm{R}$ & $\mathrm{R}$ & $\mathrm{R}$ \\
\hline American Robin & W & W & W & W & W \\
\hline Bald Eagle & $\mathrm{R}$ & & & & \\
\hline Bank Swallow & & W & W & & \\
\hline Barn Owl & & $\mathrm{R}$ & & & \\
\hline Barn Swallow & W & W & & & \\
\hline Bewick's Wren & & W & & & \\
\hline Black-billed Magpie & & $\mathrm{R}$ & W & W & W \\
\hline Black-capped Chickadee & & & $S$ & & S \\
\hline Black-headed Grosbeak & & $\mathrm{R}$ & & & \\
\hline Brewer's Blackbird & W & & W & & W \\
\hline Bufflehead & $\mathrm{R}$ & & & & \\
\hline Bullock's Oriole & $\mathrm{R}$ & $\mathrm{R}$ & & & \\
\hline California Gull & W & & & & \\
\hline California Quail & W & W & W & $\mathrm{R}$ & $S$ \\
\hline Canada Goose & W & & $\mathrm{R}$ & & \\
\hline Cassin's Finch & $\mathrm{R}$ & & & & \\
\hline Cassin's Vireo & & & $\mathrm{R}$ & & $\mathrm{R}$ \\
\hline Cedar Waxwing & $S$ & $S$ & $S$ & & W \\
\hline Chipping Sparrow & $S$ & W & $S$ & $S$ & W \\
\hline Cinnamon Teal & & $\mathrm{R}$ & & & \\
\hline Common Loon & $\mathrm{R}$ & & & & \\
\hline Common Merganser & $\mathrm{R}$ & & & & \\
\hline Common Nighthawk & & & & & $S$ \\
\hline Common Raven & $\mathrm{R}$ & $\mathrm{R}$ & $S$ & & $\mathrm{R}$ \\
\hline Cooper's Hawk & & & & & $\mathrm{R}$ \\
\hline
\end{tabular}




\begin{tabular}{|c|c|c|c|c|c|}
\hline \multirow[b]{2}{*}{ Species } & Clear Lake & Wildlife & T\&E & Fairchild & JPRA \\
\hline & \multicolumn{5}{|c|}{$\mathrm{W}=$ widespread. $\mathrm{S}=$ scattered. $\mathrm{R}=$ rare $(<3)$} \\
\hline Common Yellowthroat & & $\mathrm{S}$ & & & \\
\hline Dark-eyed Junco & & & $\mathrm{R}$ & & $\mathrm{R}$ \\
\hline Double-crested Cormorant & $\mathrm{S}$ & & & & \\
\hline Downy Woodpecker & $\mathrm{R}$ & & $\mathrm{R}$ & $\mathrm{R}$ & \\
\hline Dusky Flycatcher & & & $\mathrm{R}$ & & $\mathrm{R}$ \\
\hline Eastern Kingbird & & $\mathrm{S}$ & S & & \\
\hline Eurasian Collared-dove & & & & $S$ & \\
\hline European Starling & W & W & W & W & W \\
\hline Gadwall & $\mathrm{R}$ & $\mathrm{R}$ & & & \\
\hline Grasshopper Sparrow & & & W & & \\
\hline Gray Catbird & $\mathrm{R}$ & $\mathrm{S}$ & & & \\
\hline Great Blue Heron & W & $\mathrm{R}$ & $\mathrm{R}$ & & \\
\hline Great-horned Owl & $\mathrm{R}$ & $\mathrm{R}$ & & $\mathrm{R}$ & \\
\hline Green-winged Teal & $\mathrm{R}$ & $\mathrm{R}$ & & & \\
\hline Hammond's Flycatcher & & & & & $\mathrm{R}$ \\
\hline Hooded Merganser & $\mathrm{R}$ & & & & \\
\hline Horned Lark & & & & $\mathrm{R}$ & \\
\hline House Finch & W & W & W & W & $\mathrm{R}$ \\
\hline House Sparrow & W & & & $\mathrm{R}$ & \\
\hline House Wren & $\mathrm{R}$ & $\mathrm{S}$ & W & W & W \\
\hline Killdeer & W & W & W & W & W \\
\hline Lazuli Bunting & & & $S$ & & \\
\hline Mallard & & $S$ & $\mathrm{R}$ & & \\
\hline Marsh Wren & & $S$ & & & \\
\hline Merlin & & & & & $\mathrm{R}$ \\
\hline Mountain Chickadee & & $\mathrm{R}$ & $\mathrm{R}$ & W & W \\
\hline Mourning Dove & W & W & W & W & $S$ \\
\hline Northern Flicker & $\mathrm{S}$ & W & W & $\mathrm{R}$ & $S$ \\
\hline Northern Goshawk & $\mathrm{R}$ & $\mathrm{R}$ & & & \\
\hline Northern Harrier & & & $\mathrm{R}$ & & \\
\hline Northern Rough-winged Swallow & & W & & & \\
\hline Orange-crowned Warbler & & & $\mathrm{R}$ & $\mathrm{R}$ & \\
\hline Osprey & W & $\mathrm{R}$ & W & & \\
\hline Pied-billed Grebe & $\mathrm{S}$ & & & & \\
\hline Pine Siskin & $\mathrm{S}$ & $\mathrm{R}$ & & & $\mathrm{R}$ \\
\hline Pygmy Nuthatch & $\mathrm{S}$ & & $S$ & & $\mathrm{~S}$ \\
\hline Red-breasted Nuthatch & $\mathrm{R}$ & $\mathrm{R}$ & $\mathrm{R}$ & $\mathrm{R}$ & \\
\hline Red Crossbill & & & & & $\mathrm{R}$ \\
\hline Redhead & $\mathrm{R}$ & & & & \\
\hline
\end{tabular}




\begin{tabular}{|c|c|c|c|c|c|}
\hline \multirow[b]{2}{*}{ Species } & Clear Lake & Wildlife & T\&E & Fairchild & JPRA \\
\hline & \multicolumn{5}{|c|}{$\mathrm{W}=$ widespread. $\mathrm{S}=$ scattered. $\mathrm{R}=$ rare $(<3)$} \\
\hline Red-tailed Hawk & W & W & $\mathrm{S}$ & W & \\
\hline Red-winged Blackbird & W & W & & & \\
\hline Ring-billed Gull & W & $\mathrm{R}$ & $\mathrm{R}$ & & $\mathrm{R}$ \\
\hline Ring-necked Pheasant & & W & $\mathrm{R}$ & & $\mathrm{R}$ \\
\hline Rock Dove/Pigeon & & $\mathrm{R}$ & S & & W \\
\hline Ruby-crowned Kinglet & $\mathrm{R}$ & $\mathrm{R}$ & $\mathrm{R}$ & & \\
\hline Rufous Hummingbird & & & & & $\mathrm{R}$ \\
\hline Savannah Sparrow & & W & W & & $\mathrm{R}$ \\
\hline Say's Phoebe & $\mathrm{R}$ & $\mathrm{R}$ & $\mathrm{R}$ & $\mathrm{R}$ & W \\
\hline Sharp-tailed Grouse & & $S$ & & & \\
\hline Song Sparrow & W & W & W & $\mathrm{R}$ & $\mathrm{R}$ \\
\hline Sora & & $S$ & & & \\
\hline Spotted Towhee & & $\mathrm{R}$ & & & $\mathrm{R}$ \\
\hline Swainson's Hawk & & $\mathrm{R}$ & & $\mathrm{R}$ & \\
\hline Townsend's Solitaire & & & & & $\mathrm{R}$ \\
\hline Townsend's Warbler & & $\mathrm{R}$ & & & \\
\hline Tree Swallow & W & W & $\mathrm{R}$ & & $S$ \\
\hline Turkey Vulture & & $\mathrm{R}$ & & & \\
\hline Vesper Sparrow & & $\mathrm{R}$ & $S$ & & $\mathrm{~S}$ \\
\hline Violet-green Swallow & $\mathrm{W}$ & $\mathrm{S}$ & $\mathrm{R}$ & & W \\
\hline Western Bluebird & & & & & $S$ \\
\hline Western Kingbird & & $\mathrm{R}$ & W & $\mathrm{R}$ & \\
\hline Western Meadowlark & & W & W & $\mathrm{R}$ & W \\
\hline Western Screech-owl & & $\mathrm{R}$ & & & \\
\hline Western Tanager & & & $\mathrm{R}$ & & \\
\hline Western Wood Pewee & W & W & W & $\mathrm{S}$ & W \\
\hline White-breasted Nuthatch & $\mathrm{R}$ & & $\mathrm{R}$ & & $\mathrm{R}$ \\
\hline White-crowned Sparrow & $\mathrm{R}$ & $\mathrm{S}$ & $S$ & & $\mathrm{R}$ \\
\hline White-throated Swift & & $\mathrm{R}$ & & & $\mathrm{R}$ \\
\hline Wild Turkey & & & & & $\mathrm{R}$ \\
\hline Willow Flycatcher & $\mathrm{R}$ & $\mathrm{R}$ & & & \\
\hline Wilson's Snipe & & W & & & \\
\hline Winter Wren & $\mathrm{R}$ & $\mathrm{R}$ & & & \\
\hline Wood Duck & $\mathrm{R}$ & & & & \\
\hline Yellow Warbler & $\mathrm{R}$ & & $\mathrm{R}$ & & $\mathrm{R}$ \\
\hline Yellow-rumped Warbler & $\mathrm{R}$ & $\mathrm{R}$ & & $\mathrm{R}$ & $\mathrm{R}$ \\
\hline Yellow-headed Blackbird & & $\mathrm{S}$ & & & \\
\hline
\end{tabular}




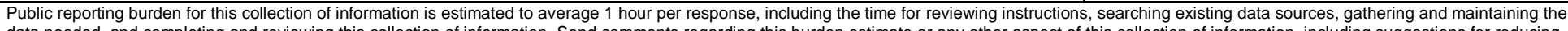

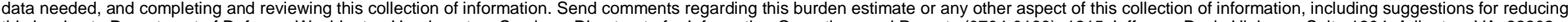

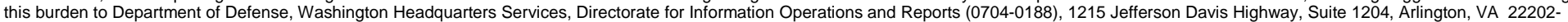

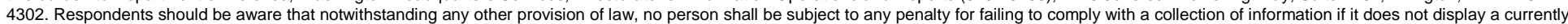
valid OMB control number. PLEASE DO NOT RETURN YOUR FORM TO THE ABOVE ADDRESS.

\begin{tabular}{|l|c|c|}
\hline 1. REPORT DATE (DD-MM-YYYY) & 2. REPORT TYPE & 3. DATES COVERED (FrOm - To)
\end{tabular}

\section{TITLE AND SUBTITLE}

Final

Avian and Herpetological Survey Results for Fairchild Air Force Base and Ancillary Properties

\section{5a. CONTRACT NUMBER}

5b. GRANT NUMBER

\section{5c. PROGRAM ELEMENT}

\section{5d. PROJECT NUMBER}

MIPR

5e. TASK NUMBER

5f. WORK UNIT NUMBER

. F1X3011187Go01

8. PERFORMING ORGANIZATION REPORT NUMBER

ERDC/CERL TR-14-27

Construction Engineering Research Laboratory (CERL)

PO Box 9005,

Champaign, IL 61826-9005

\section{SPONSORING / MONITORING AGENCY NAME(S) AND ADDRESS(ES)}

Fairchild Air Force Base (FAFB)

92nd Civil Engineer Squadron

100 West Ent Street, Suite 155

Fairchild AFB, WA 99011

\section{DISTRIBUTION / AVAILABILITY STATEMENT}

Approved for public release; distribution is unlimited.
10. SPONSOR/MONITOR'S ACRONYM(S) FAFB

11. SPONSOR/MONITOR'S REPORT NUMBER(S)

\section{SUPPLEMENTARY NOTES}

\section{ABSTRACT}

Many reptile, amphibian (collectively termed "herpetofauna”), and avian populations are declining at a precipitous rate. Department of Defense (DoD) installations likely serve as refuges of intact critical habitat for avian and herpetofaunal species. As more species become a conservation concern, it becomes increasingly important for DoD land managers to document the species that currently exist on their lands and, through proactive management, avoid potential conflicts between conservation measures and military training. DoD installations will likely assume the task of protecting threatened and endangered herpetofaunal species. Installation land management practices will maintain the long-term viability of these species’ populations. The first step in developing a process to successfully manage wildlife species on DoD installations is to survey their populations. This work surveyed avian and herpetofaunal populations on Fairchild Air Force Base (FAFB) and used survey results to extrapolate guidelines for species management.

\section{SUBJECT TERMS}

Fairchild AFB, land management, natural resource management plan, threatened and endangered species (TES)

\section{SECURITY CLASSIFICATION OF:}

a. REPORT

Unclassified

\section{b. ABSTRACT}

Unclassified c. THIS PAGE

Unclassified

17

\section{LIMITATION} OF ABSTRACT

SAR

\section{NUMBER} OF PAGES

35 19a. NAME OF RESPONSIBLE PERSON

19b. TELEPHONE NUMBER (include area code) 